\title{
Inquest of efficient photo-assist advanced oxidation processes (AOPs) for removal of azo dye (acid yellow 17) in aqueous medium: a comprehensive study on oxidative decomposition of AY 17
}

\author{
Muhammad Tariq $^{1}$ (D) Jehangeer Khan ${ }^{1}$
}

Received: 30 March 2020 / Accepted: 14 October 2020 / Published online: 24 October 2020

(c) Springer Nature Switzerland AG 2020

\begin{abstract}
In this study, the photo-assist degradation of acid yellow (AY 17) dye is reported in detail by applying various UV radiation supported advanced oxidation processes (AOPs). The AY 17 dye in water solution (model and natural) is decomposed by direct photolysis, UV/oxidant, photo-Fenton, photo-Fenton-like, UV/ $\mathrm{HSO}_{5}{ }^{-} / \mathrm{Fe}^{2+}$, and UV/S $\mathrm{O}_{8}{ }^{2-} / \mathrm{Fe}^{2+}$ system. All applied processes are found to be the comparably effective at $\mathrm{pH}$ 3.0. It is observed that the efficiency of $\mathrm{AY} 17$ degradation increased with the initial concentration of the oxidants $\left(\mathrm{H}_{2} \mathrm{O}_{2}, \mathrm{HSO}_{5}{ }^{-}\right.$and $\left.\mathrm{S}_{2} \mathrm{O}_{8}{ }^{2-}\right)$ and catalyst $\left(\mathrm{Fe}^{2+}\right.$ and Fe $\left.{ }^{3+}\right)$. Moreover, the initial concentration of the dye solution has inverse effect on the efficiency of applied AOPs. It is also reported that decomposition of dye through photo-assist AOPs followed pseudo-first-order kinetic while the efficiency of all processes increased with temperature. The activation energy $\left(E_{\mathrm{a}}\right)$ has been determined in the range of between $10 \mathrm{to} 20 \mathrm{~kJ} / \mathrm{mol}$. The entropy of degradation is also calculated and has found to be positive. Finally, it is concluded that photo-Fenton process $\left(\mathrm{UV} / \mathrm{H}_{2} \mathrm{O}_{2} / \mathrm{Fe}^{2+}\right)$ is comparably more efficient method for the removal of AY 17 dye from natural water sample.
\end{abstract}

Keywords Azo dye $\cdot$ Waste water treatment $\cdot$ UV light assist AOP $\cdot$ Hydroxyl radical $(\cdot \mathrm{OH}) \cdot$ Sulphate radical $\left(\mathrm{SO}_{4}{ }^{-}\right)$

\section{Introduction}

Advanced oxidation processes (AOPs) may be defined as "the processes in which highly reactive species like hydroxyl radical ( $\mathrm{OH})$, hydrated electron $\left(\mathrm{e}^{-}{ }_{\mathrm{aq}}\right)$, or sulphate radical $\left(\mathrm{SO}_{4}{ }^{-}\right)$are produced in sufficient amount at near ambient temperature and pressure" [1]. These processes show efficient results in the purification of surface and ground water and in the degradation of biodegradable and non-biodegradable organic toxic wastes. To produce reactive radicals, various oxidants such as hydrogen peroxide, persulfate, peroxydisulphate $\left(\mathrm{S}_{2} \mathrm{O}_{8}{ }^{2-}\right)$ or simply called PS, and PMS (permonoxysulphate, $\mathrm{HSO}_{5}{ }^{-}$) are used. The hydroxyl radical is simpler and more reactive which is used in different advance oxidation technologies, like Fenton, Fenton like, photo Fenton etc., reactions. Under appropriate conditions, it leads to mineralization, i.e., its end products are water and carbon dioxide. Therefore $\mathrm{OH}$ radical is an environment friendly oxidizing agent. Because of its properties, $\mathrm{H}_{2} \mathrm{O}_{2}$ plays significant role in the fields of green engineering and chemistry $[2,3]$

A novel oxidant, persulfate $\left(\mathrm{S}_{2} \mathrm{O}_{8}{ }^{2-}\right)$ showed a versatile efficiency in the field of AOPs. It has certain advantages, like low cost, high water solubility, moderate stability, easy to store, and high redox potential [4]. Another advantage of $\mathrm{S}_{2} \mathrm{O}_{8}{ }^{2-}$ (PS) is that it is less reactive towards natural organic matters but appears to be more reactive towards aqueous solution which contains high value of natural organic matter (NOMs) [5]. Due to these properties, $\mathrm{S}_{2} \mathrm{O}_{8}{ }^{2-}$ (PS) is a more effective oxidant for the treatment of wastewater. The third oxidant, $\mathrm{HSO}_{5}{ }^{-}$, is an active ingredient of oxone in aqueous solution and it trade name is triple

Muhammad Tariq,dr.muhammadtariq@uop.edu.pk; $\bowtie$ Jehangeer Khan, jkncepc@uop.edu.pk|'1National Centre of Excellence in Physical Chemistry, University of Peshawar, Peshawar 25120, Pakistan. 
salt of potassium $\left(2 \mathrm{KHSO}_{4} \cdot \mathrm{KHSO}_{4} \cdot \mathrm{K}_{2} \mathrm{SO}_{4}\right)$. In recent years $\left(\mathrm{HSO}_{5}{ }^{-}\right)$has shown a tremendous role in the treatment of wastewater $[2,6,7]$.

Since the redox potentials of $\mathrm{HSO}_{5}{ }^{-}$(PMS), $\mathrm{S}_{2} \mathrm{O}_{8}{ }^{2-}$ (PS) and hydrogen peroxide $\left(\mathrm{H}_{2} \mathrm{O}_{2}\right)$ are low so these cannot oxidize organic pollutants efficiently. The transition metal ion $\left(\mathrm{Mn}^{2+}, \mathrm{Fe}^{2+}, \mathrm{Fe}^{3+}, \mathrm{Ni}^{2+}\right.$, etc.) can activate the oxidant through electron transfer mechanism to produce highly reactive radicals which can successfully degrade the toxic pollutants. When $\mathrm{H}_{2} \mathrm{O}_{2}$ is activated by ferrous ions, $\mathrm{Fe}^{2+}$, this process is known as Fenton process. It is an important oxidizing process which is applied for the oxidation of organic pollutant since long time in the history of wastewater treatment. In Fenton process, hydroxyl radical ( $(\mathrm{OH})$ is produced which attacks the pollutant and oxidizes them to less toxic compounds, such as inorganic salts, $\mathrm{H}_{2} \mathrm{O}$ and $\mathrm{CO}_{2}$. It is a simple, easily handled and relatively cheaper process but it works under acidic conditions, i.e., optimum $\mathrm{pH}$ between 3.0 and 4.0, which is the main drawback of this process [8].

When the oxidants like $\mathrm{H}_{2} \mathrm{O}_{2}, \mathrm{HSO}_{5}{ }^{-}$and $\mathrm{S}_{2} \mathrm{O}_{8}{ }^{-}$are activated by ferric ion $\left(\mathrm{Fe}^{3+}\right)$ then this process is called Fentonlike process $[9,10]$. Fenton-like process is based on the production of hydroxyl or sulfate or both radicals. The oxidant can also be activated by other metal ions like $\mathrm{V}^{3+}, \mathrm{Ce}^{3+}$, $\mathrm{Ru}^{3+}, \mathrm{Mn}^{2+}, \mathrm{Ni}^{2+}, \mathrm{Ag}^{+}$and $\mathrm{Co}^{2+}[11]$. All the above types of metals ions generate the same $\mathrm{OH}$ and $\mathrm{SO}_{4}{ }^{-}$radicals. However, the efficiency of metal ions to produce reactive radical may be different.

The combination of UV radiation with $\mathrm{H}_{2} \mathrm{O}_{2} / \mathrm{Fe}^{2+}$ and $\mathrm{H}_{2} \mathrm{O}_{2} / \mathrm{Fe}^{3+}$ are known photo Fenton and photo Fentonlike processes, respectively. The presence of UV radiation with Fenton and Fenton-like processes increases the degradation efficiency of these processes [5]. The difference between photo Fenton and photo Fenton-like processes is only the use of iron ( $\mathrm{Fe}$ ) as catalyst in different oxidation state. The production rate of reactive radicals and regeneration of $\mathrm{Fe}^{2+}$ and $\mathrm{Fe}^{3+}$ from its complex can also be enhanced by using UV radiation [11]. All the processes such as, photo-Fenton, photo-Fenton-like, $\mathrm{UV} / \mathrm{HSO}_{5}{ }^{-} / \mathrm{Fe}^{2+}$ and $\mathrm{UV} / \mathrm{H}_{2} \mathrm{SO}_{8}{ }^{2-} / \mathrm{Fe}^{2+}$ are economic, environmentally friendly and very effective. Several photo-assist AOPs are shown in diagram (Fig. 1).

Azo dye-acid Yellow 17 have complicated and stable structure (see Table 1). It has a strong electron withdrawing character which stabilizes azo dyes against conversion by oxygenase in aerobic environment [12]. Under anaerobic conditions azo dyes are converted to toxic end products i.e. aromatic amines [13]. These aromatic amines are also mutagenic and carcinogenic [14]. It can cause various problems and diseases in humans and in aquatic life. It can affect respiratory system e.g., dyspnea, skin disease dermatitis, cardiovascular disease, eye irritation, nervous

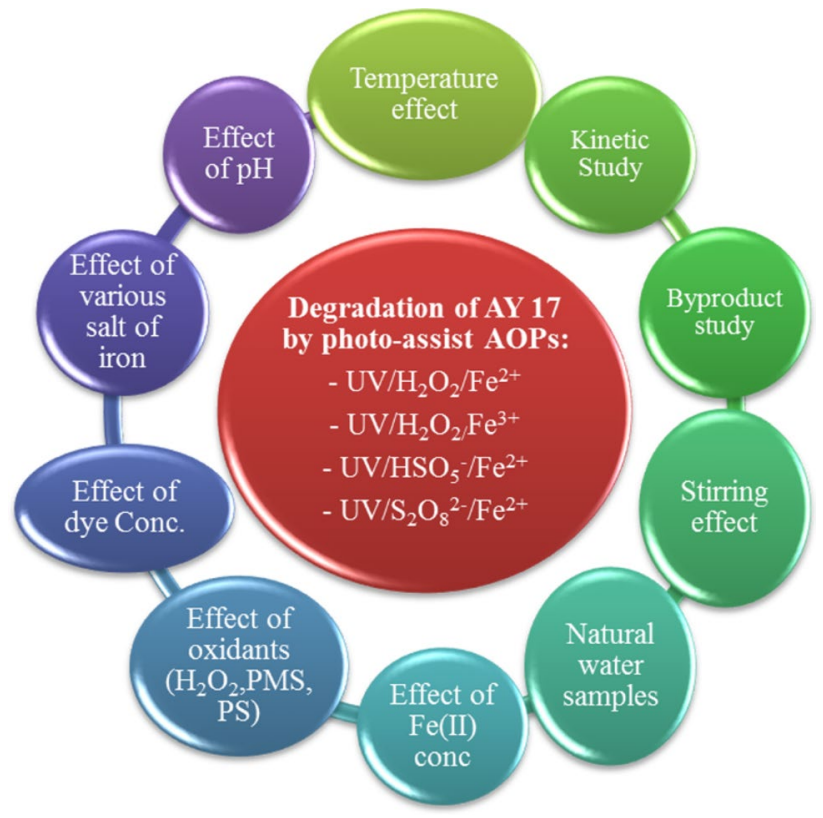

Fig. 1 Scheme of the present study

Table 1 Physical and chemical properties of acid yellow 17

\begin{tabular}{ll}
\hline Azo dye & Acid yellow 17 \\
\hline MW & $551.277 \mathrm{~g} / \mathrm{mol}$ \\
Solubility in $\mathrm{H}_{2} \mathrm{O}$ & Soluble \\
$\mathrm{C.I}$ & 18,965 \\
$\lambda_{\max }$ & $400 \mathrm{~nm}$ \\
$\mathrm{PK}_{\mathrm{a}}$ & 5.3 \\
Molecular structure & $\mathrm{NaO}$
\end{tabular}

system of human being and other animals [15]. The present work therefore demonstrates the decomposition of AY 17 by UV light assist AOPs which include a comprehensive comparative study-utilizing several effective, easy and environmental friendly AOPs such as direct photolysis, UV/ Oxidant, Fenton, Fenton-like, photo-Fenton, PhotoFenton-like, UV/ $/ \mathrm{SO}^{5-} / \mathrm{Fe}^{2+}$ and $\mathrm{UV} / \mathrm{S}^{2} \mathrm{O}_{8}{ }^{-} / \mathrm{Fe}^{2+}$ for removal of acid yellow 17 dye in aqueous medium. A comparison in the efficiency, reaction kinetic, and mechanism for degradation of AY 17 dye in aqueous medium by AOPs of different AOPs is also investigated. Finally, the degradation of on AY 17 dye solution in pure water and natural water was carried out to assess the efficacy of UV light assist AOPs. To the best of our knowledge, the Photo-Fenton-like, UV/ 
$\mathrm{HSO}^{5-} / \mathrm{Fe}^{2+}$ and $\mathrm{UV} / \mathrm{S}_{2} \mathrm{O}^{8-} / \mathrm{Fe}^{2+}$ is applied for the first time for the degradation of acid yellow 17 dye. The effect of several parameters (as sketched in Fig. 1) on the decomposition of AY 17 are investigated.

\section{Experimental}

\subsection{Chemical and reagents}

Acid yellow 17 dye (Cat. No. 191921000, dye content 60\%) was purchased from Acros Organics (Belgium). hydrogen peroxide $\left(\mathrm{H}_{2} \mathrm{O}_{2}, 30 \% \mathrm{w} / \mathrm{w}\right.$, analytical grade), ferrous sulfate hepta hydrated) (purity $\geq 99.5 \%$, analytical grade)), ferric sulfate $\left(\mathrm{FeSO}_{4}\right.$, purity $\geq 98 \%$, reagent grade), sodium nitrate $\left(\mathrm{NaNO}_{3}\right.$, purity $98 \%$, analytical grade), sodium nitrite $\left(\mathrm{NaNO}_{2}\right.$, purity $98 \%$, analytical grade) and buffer solutions ( $\mathrm{pH} 4.0,7.0$ and $\mathrm{pH} 11.0$ ) were purchased from Scharlau, Germany. Sulfuric acid $\left(\mathrm{H}_{2} \mathrm{SO}_{4}\right.$, purity $\geq 99.99 \%$, analytical grade), sodium bicarbonate $\left(\mathrm{NaHCO}_{3}\right.$, purity $\geq 99.5 \%$, analytical grade), potassium iodate (purity $98 \%$, analytical grade), potassium iodide (purity $\geq 99 \%$, analytical grade), potassium dichromate (purity $\geq 99 \%$, analytical grade), and sodium carbonate $\left(\mathrm{NaCO}_{3}\right.$, purity $\geq 98 \%$, analytical grade) were purchased from Sigma Aldrich, Germany. Potassium chloride $(\mathrm{KCl})$ and Sodium chloride $(\mathrm{NaCl})$ of analytical grade from Merck, (U.S.A) were used. All required standard solutions were prepared in Milli-Q ultra-pure water (Re\$\$sistivity $\geq 18.2 \mathrm{M} \Omega . \mathrm{cm}$ ). For adjustment of $\mathrm{pH}$ of solutions, dilute solutions of $\mathrm{H}_{2} \mathrm{SO}_{4}$ and $\mathrm{NaOH}$ were used.

\subsection{Instrumentations}

Millipore Milli-Q system (Bedford, U.S.A) was used to obtain ultra-pure water. For drying purposes, electronic oven (WTC Binder E 28, Germany) was used. The pH of solution was measured by $\mathrm{pH}$ meter (NeoMet ISTEC, Korea). For weighing purposes, digital microbalance AY220 (Shimadzo, Germany) was used. UV-visible spectrophotometer (Perkin Elmer, Model: Lambda-650, UK) was used for the quantitative analysis. For the absorbance calibration of UV-visible spectrophotometer, standard solution of $\mathrm{K}_{2} \mathrm{Cr}_{2} \mathrm{O}_{7}$ was used. Percent degradation was calculated using Eq. (1).

Percent degradation $=\left(\frac{C_{t}}{C_{0}}\right) \times 100 \%$

where, $C_{0}$ is the initial concentration of AY 17 at $t=0.0$ min, while $C_{t}$ is the concentration of AY 17 at time $t$ min which was calculated from the absorbance measurement through Beer's Lambert law.
For the photolysis of aqueous solution of AY 17 dye, a photochemical apparatus fitted with a $4 \mathrm{~W}$ low pressure Hg-UV lamp (PENRAY, USA) was used. The wavelength of the light emitted by Hg-UV lamp was $254 \mathrm{~nm}$. The lamp was enclosed in wooden box. A magnetic stirrer was used for stirring the sample to achieve homogenous flow of UV radiation through solution. The area of Pyrex glass beaker was 50 $\mathrm{cm}^{2}$ which was used for sample solution for UV radiation treatment.

For the quantitative and qualitative analysis of anions and cations present in natural waters, Metrohm lon chromatograph 800 series equipped with electrical conductivity was used. The columns used for analysis of anions and cations were Metrosep A supp $5(250 / 4.0 \mathrm{~mm})$ and Metrosep $C_{1}(125 / 4.6 \mathrm{~mm})$ respectively. For anions analysis the ion-chromatographic determination were carried out with $50 \mathrm{mM} \mathrm{H}_{2} \mathrm{SO}_{4} / 1 \mathrm{mM} \mathrm{NaHCO} / 3.2 \mathrm{mMNa}_{2} \mathrm{CO}_{3} /$ milli-Q water as mobile phase. In case of cations analysis, the mobile phase was tartaric acid / $24 \mathrm{mM}$ boric acid / $1 \mathrm{mM}$ dipiclonic acid.

For identification of intermediates of AY 17 dye produced during the oxidation GC-MS analysis was performed by using a HP-6890 gas chromatograph coupled with a HP-5973 mass spectrometry instrument. With the help of HP-5 MS capillary column $(30 \mathrm{~m} \times 0.25 \mathrm{~mm} \times 0.25 \mu \mathrm{m})$ separation of the sample components was achieved. Mass spectra were obtained by the electron-impact mode (El) at $70 \mathrm{eV}$, using scan mode $(50-500 \mathrm{~m} / \mathrm{z})$ under these conditions: purge time $=1 \mathrm{~min}$, purge flow $=26.5 \mathrm{ml} . \mathrm{min}^{-1}$ and pressure $=7.63$ psi. GC-MS information was compared with NIST mass spectra library for identification of unknown compounds.

\section{Result and discussion}

\subsection{Photo-Fenton process $\left(\mathrm{UV} / \mathrm{H}_{2} \mathrm{O}_{2} / \mathrm{Fe}^{2+}\right)$}

Prior to photo-Fenton process $\left(\mathrm{UV} / \mathrm{H}_{2} \mathrm{O}_{2} / \mathrm{Fe}^{2+}\right)$, the degradation of AY 17 dye was first checked with UV, UV/Fe ${ }^{2+}, \mathrm{UV} /$ $\mathrm{H}_{2} \mathrm{O}_{2}$ system. It was observed that only $2 \%, 3 \%$, and $5 \%$ dye was degraded with UV light, UV/Fe ${ }^{2+}, \mathrm{UV} / \mathrm{H}_{2} \mathrm{O}_{2}$ system in $25 \mathrm{~min}$ at optimized experimental conditions, respectively (Fig. 2, Table. 2). In contrast, about $88.00 \%$ degradation in 25 min was achieved with $\mathrm{UV} / \mathrm{H}_{2} \mathrm{O}_{2} / \mathrm{Fe}^{2+}$ system. The reason for high percent degradation with $\mathrm{UV} / \mathrm{H}_{2} \mathrm{O}_{2} / \mathrm{Fe}^{2+}$ system is the frequent availability of both oxidant $\left(\mathrm{H}_{2} \mathrm{O}_{2}\right)$ and catalyst $\left(\mathrm{Fe}^{2+}\right)$ in the system which facilitate the degradation process by producing large number of hydroxyl radical $(\mathrm{OH})$ as shown by Eqs. (2-4) [16].

$$
\begin{aligned}
& \mathrm{H}_{2} \mathrm{O}_{2}+\mathrm{Fe}^{2+} \rightarrow \mathrm{OH}+{ }^{-} \mathrm{OH}+\mathrm{Fe}^{3+} \\
& \mathrm{H}_{2} \mathrm{O}_{2}+\mathrm{Fe}^{3+} \rightarrow \mathrm{HOO}+\mathrm{Fe}^{2+}+\mathrm{H}^{+}
\end{aligned}
$$




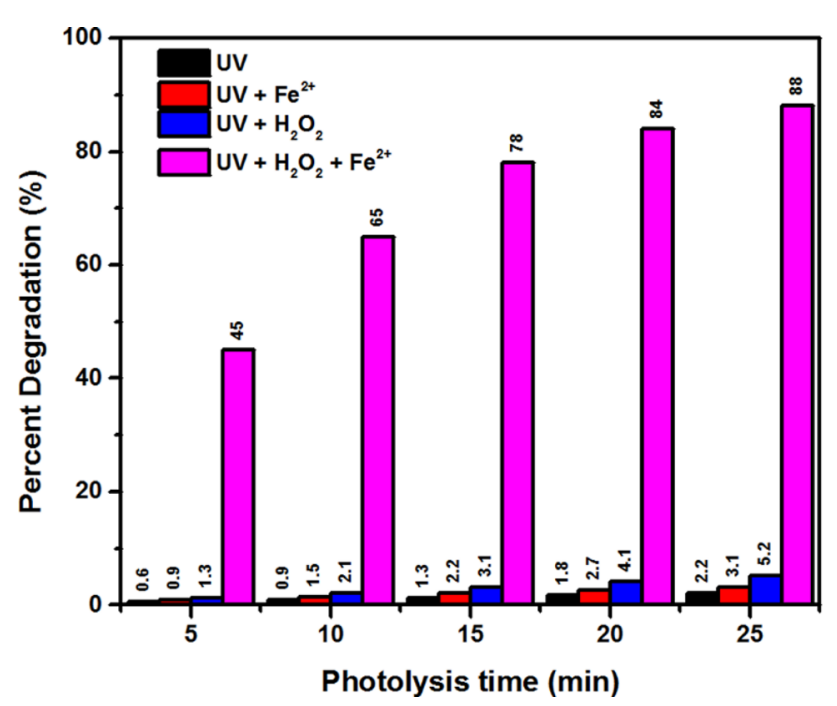

Fig. 2 Degradation of $A Y 17$ dye at experimental optimized condition: $\mathrm{pH}=3.0,\left[\mathrm{H}_{2} \mathrm{O}_{2}\right]_{0}=1.0 \mathrm{mM}, \quad[\mathrm{AY} \quad 17]_{0}=0.14 \mathrm{mM}$, $\left[\mathrm{Fe}^{2+}\right]_{0}=0.09 \mathrm{mM}, \mathrm{T}=298 \mathrm{~K}$

$\mathrm{H}_{2} \mathrm{O}_{2}+\mathrm{hv} \rightarrow 2 \cdot \mathrm{OH}$

It was observed that photo-Fenton process is highly effective at $\mathrm{pH} 3.0$ due to formation of $[\mathrm{FeOH}]^{2+}$. The $U V$ radiation accelerates the conversion of $[\mathrm{FeOH}]^{2+}$ into $\mathrm{Fe}^{2+}$ ion and $\cdot \mathrm{OH}$ and thus the degradation process improved (Eq. 5) [17, 18].

$[\mathrm{FeOH}]^{2+}+\mathrm{hv} \rightarrow \mathrm{Fe}^{2+}+\mathrm{OH}$

The degradation of photo-Fenton process also effected with concentration of oxidant $\left(\mathrm{H}_{2} \mathrm{O}_{2}\right)$ The increased in degradation in with concentration of $\mathrm{H}_{2} \mathrm{O}_{2}$ is due to production of $\mathrm{OH}$ radical (Eq. 4) [19]. Since, $\mathrm{Fe}^{2+}$ concentration directly affects the yield of $\mathrm{OH}$ radical as shown in (Eq. 2), a concentration of $0.09 \mathrm{mM} \mathrm{Fe}^{2+}$ was found as optimum $\mathrm{Fe}^{2+}$ concentration.

Initial concentration of AY 17 is another important parameter for degradation by photo-Fenton process. In present study the concentration of AY 17 dye varied from 0.1 to $0.22 \mathrm{mM}$ was investigated. The optimum concentration of Ay 17 was attained. The effect of stirring velocity on degradation of AY 17 by photo-Fenton process, with stirring speed of 0, 100, 200 and, 400 rpm was also studied. Maximum degradation is achieved at $100 \mathrm{rpm}$. The reason for these fluctuations may be due to the aspiration of gases such as $\mathrm{O}_{2}$ and $\mathrm{CO}_{2}$ into solutions [20]. Under the influence high velocity of stirring $\mathrm{CO}_{2}$ in the solution which produce $\mathrm{HCO}_{3}^{-}$and $\mathrm{CO}_{3}{ }^{2-}$ ions (Eq. 6-7). The degradation was decreased due to the reaction of these ion complex (Eq. 8-11). The $\mathrm{CO}_{3}{ }^{2-}$ and $\mathrm{HCO}_{3}{ }^{-}$ions produced can scavenge hydroxyl radical. The degradation decreased due to the consumption of $\mathrm{OH}$ radical ( Eq. 12,13) [21]. Similarly, the effect of $\mathrm{CO}_{3}{ }^{2-}$ and $\mathrm{HCO}_{3}-$ was separately investigated. It was observed that degradation of AY 17 dye decreased due to the presence of $\mathrm{CO}_{3}{ }^{2-}$ and $\mathrm{HCO}_{3}{ }^{-}$. These produced ions scavenge the production of hydroxyl radical $\mathrm{OH}$ which is important for dye degradation.

$\mathrm{CO}_{2}+\mathrm{H}_{2} \mathrm{O} \rightarrow \mathrm{HCO}_{3}^{-}+{ }^{+} \mathrm{H}$

$\mathrm{HCO}_{3}{ }^{-} \rightarrow \mathrm{CO}_{3}^{2-}+\mathrm{H}^{+}$

$\mathrm{Fe}^{2+}+\mathrm{HCO}_{3}^{-} \rightarrow \mathrm{FeHCO}_{3}^{+}$

$\mathrm{Fe}^{2+}+\mathrm{CO}_{3}^{2-} \rightarrow \mathrm{FeCO}_{3}$

$\mathrm{Fe}^{2+}+2 \mathrm{CO}_{3}^{2-} \rightarrow \mathrm{Fe}\left(\mathrm{CO}_{3}\right)_{3}^{2-}$

$\mathrm{Fe}^{2+}+\mathrm{CO}_{3}^{2-}+{ }^{-} \mathrm{OH} \rightarrow \mathrm{Fe}\left(\mathrm{CO}_{3}\right)\left({ }^{-} \mathrm{OH}\right)$
Table 2 Optimized parameter for degradation AY 17 dye

\begin{tabular}{|c|c|c|c|c|}
\hline \multirow[t]{2}{*}{ Parameter } & $\mathrm{UV} / \mathrm{H}_{2} \mathrm{O}_{2} / \mathrm{Fe}^{2+}$ & $\mathrm{UV} / \mathrm{H}_{2} \mathrm{O}_{2} / \mathrm{Fe}^{3+}$ & $\mathrm{UV} / \mathrm{HSO}_{5}{ }^{-} / \mathrm{Fe}^{2+}$ & $\mathrm{UV} / \mathrm{S}_{2} \mathrm{O}_{8}{ }^{2-} / \mathrm{Fe}^{2+}$ \\
\hline & \multicolumn{4}{|c|}{ Optimized conditions } \\
\hline $\mathrm{H}_{2} \mathrm{O}_{2}(\mathrm{mM})$ & 1.0 & 10 & - & - \\
\hline $\mathrm{HSO}_{5}^{-}(\mathrm{mM})$ & - & - & 2 & - \\
\hline $\mathrm{S}_{2} \mathrm{O}_{8}{ }^{2-}(\mathrm{mM})$ & - & - & - & 1 \\
\hline $\mathrm{Fe}^{2+}(\mathrm{mM})$ & 0.09 & - & 1 & 0.5 \\
\hline $\mathrm{Fe}^{3+}(\mathrm{mM})$ & - & 0.09 & - & - \\
\hline AY $17(\mathrm{mM})$ & 0.14 & 0.14 & 0.14 & 0.14 \\
\hline Time of Reaction (min) & 25 & 60 & 60 & 60 \\
\hline$\%$ Degradation $^{\mathrm{a}}$ & 88 & 93 & 86 & 84 \\
\hline AY 17: Oxidant: Catalyst (ratio) & 1.5: $11: 1$ & 1.5: $111: 1$ & 1:14: 7 & $1: 7: 3.7$ \\
\hline
\end{tabular}

${ }^{a}$ In triply distilled water sample 


$$
\begin{aligned}
& \cdot \mathrm{OH}+\mathrm{HCO}_{3}^{-} \rightarrow \mathrm{H}_{2} \mathrm{O}+\mathrm{CO}_{3}^{--} \\
& \mathrm{OH}+\mathrm{CO}_{3}^{2-} \rightarrow{ }^{-} \mathrm{OH}+\mathrm{CO}_{3}^{--}
\end{aligned}
$$

The presence of chloride $\left(\mathrm{Cl}^{-}\right)$also decreases the degradation. The decreased in degradation was due to the scavenging of hydroxyl radical by chloride ion. By addition of chloride ion, various inorganic radical like $\mathrm{ClOH}^{-}, \mathrm{HClOH}^{\circ}$, $\mathrm{Cl}^{\prime}$ and $\mathrm{Cl}_{2}$ 'were produced. Among all these the $\mathrm{Cl}_{2}$ is the pre-dominant species due to which the degradation rate drastically decreased by inhibition of $\mathrm{OH}$ radical production [22].

Similarly, the degradation also decreased with $\mathrm{SO}_{4}{ }^{2-}$ concentration The reason for the decreased in degradation due to sulphate ion $\left(\mathrm{SO}_{4}{ }^{2-}\right)$ was the reaction of sulphate anion with both Ferric and ferrous ions, which form complexes such as $\mathrm{FeSO}_{4}, \mathrm{FeSO}_{4}{ }^{+}$and $\mathrm{Fe}(\mathrm{OH})^{2}$ [23]. The adjustment of initial temperature plays a very important role in the degradation of dyes by AOPs. High temperature (in the range of $298 \mathrm{~K}-318 \mathrm{~K}$ ) also improved generation of $\mathrm{OH}$ radical hence favors high decomposition of dye. At high temperature the concentration of $[\mathrm{FeOH}]^{2+}$ increased which result an increased in photo-production of $\mathrm{Fe}^{2+}$ from $[\mathrm{FeOH}]^{2+}$ (Eq. 5) $[24,25]$.

\subsection{Photo-Fenton-like process $\left(\mathrm{UV} / \mathrm{H}_{2} \mathrm{O}_{2} / \mathrm{Fe}^{3+}\right)$}

The percent degradation by $\mathrm{UV} / \mathrm{H}_{2} \mathrm{O}_{2} / \mathrm{Fe}^{3+}$ systems was found to be $93 \%$ in $60 \mathrm{~min}$ at optimized condition (shown in Table. 2, Fig. 3). Various types of reaction which are occurred during photo-Fenton-like process were given below (Eqns. 14-17) [26].

$\mathrm{H}_{2} \mathrm{O}+\mathrm{UV} \rightarrow{ }^{\circ} \mathrm{OH}+{ }^{+} \mathrm{H}$

$\mathrm{Fe}^{3+}+\mathrm{H}_{2} \mathrm{O}+\mathrm{UV} \rightarrow \mathrm{Fe}^{2+}+\mathrm{OH}+{ }^{+} \mathrm{H}$

$\mathrm{Fe}^{2+}+\mathrm{H}_{2} \mathrm{O}_{2}+\mathrm{UV} \rightarrow \mathrm{Fe}^{2+}+\mathrm{HOO}^{-}+\mathrm{H}^{-}$

$\mathrm{AY} 17+\mathrm{OH} \rightarrow \mathrm{CO}_{2}+\mathrm{H}_{2} \mathrm{O}$

The experimental observation shows that photo-Fenton-like process is strongly depends upon initial $\mathrm{pH}$ of solution. The maximum degradation was achieved at $\mathrm{pH}$ 3.0. Here also the initial concentration of $\mathrm{H}_{2} \mathrm{O}_{2}$ also plays a very important role in the degradation of $A Y 17$ dye. When concentration of $\mathrm{H}_{2} \mathrm{O}_{2}$ was increased from 1 to $10 \mathrm{mM}$, the degradation of $A Y 17$ increased due to high generation of $\mathrm{OH}$ radical. But when the initial concentration of $\mathrm{H}_{2} \mathrm{O}_{2}$ increased to $20 \mathrm{mM}$ there was no significant increase in degradation was observed. This was due to the scavenging

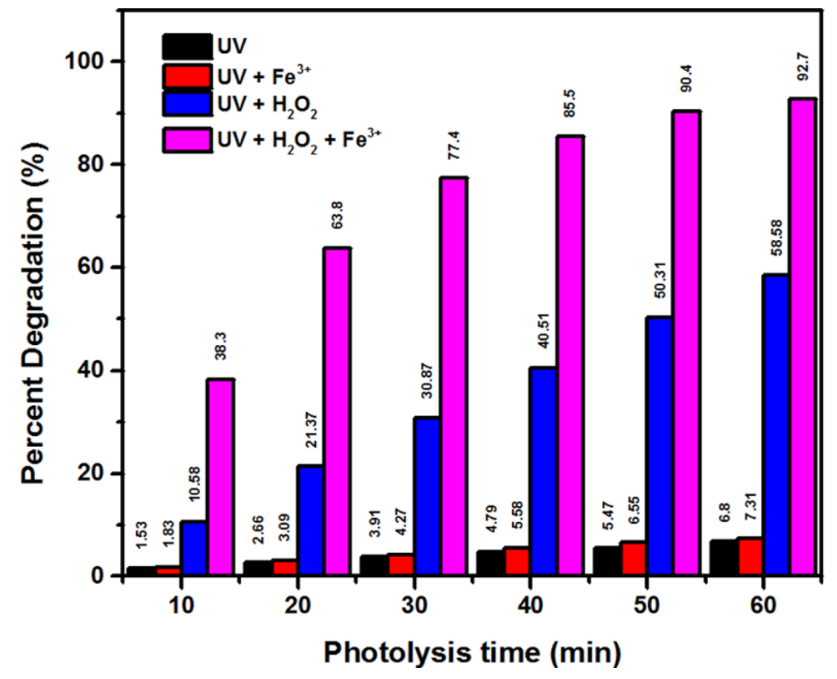

Fig. 3 Degradation of AY 17 dye at experimental optimized condition: $\left[\mathrm{H}_{2} \mathrm{O}_{2}\right]_{0}=10 \mathrm{mM},[\mathrm{AY} 17]_{0}=0.14 \mathrm{mM}$ and $\left[\mathrm{Fe}^{3+}\right]_{0}=0.09 \mathrm{mM}$ $\mathrm{pH}=3.0, \mathrm{~T}=298 \mathrm{~K}$

of $\mathrm{OH}$ radical [27]. The effect of $\mathrm{Fe}^{3+}$ and concentration of dye is also a very important parameter which require to be optimized. The optimum concentration of $\mathrm{Fe}^{3+}$ and dye was found to be $0.09 \mathrm{mM}$ and $0.14 \mathrm{mM}$, respectively. Similar to photo-Fenton, the degradation of dye through photo-Fenton like process also increased with temperature.

The effect of various salts of $\mathrm{Fe}^{3+}$ such as $\mathrm{FeCl}_{3}, \mathrm{Fe}\left(\mathrm{NO}_{3}\right)_{3}$ and $\mathrm{Fe}_{2}\left(\mathrm{SO}_{4}\right)_{3}$ were also studied. It was observed that maximum degradation was achieved by $\mathrm{Fe}_{2}\left(\mathrm{SO}_{4}\right)_{3}$ with the following order of reactivity of $\mathrm{Fe}^{3+}$ salts; $\mathrm{Fe}_{2}\left(\mathrm{SO}_{4}\right)_{3}>\mathrm{FeCl}_{3}>\mathrm{Fe}$ $\left(\mathrm{NO}_{3}\right)_{3}$. In case of $\mathrm{Fe}_{2}\left(\mathrm{SO}_{4}\right)_{3}$, highly reactive sulphatoiron(II) $\left(\mathrm{H}_{2} \mathrm{O}_{2}-\mathrm{Fe}\right.$ (II)) complex was formed which enhance degradation. The reason for low degradation in case of by $\mathrm{FeCl}_{3}$ and $\mathrm{Fe}_{2}\left(\mathrm{NO}_{3}\right)_{3}$ was due to the scavenging effect of $\mathrm{OH}$ radical by counter ions $\left(\mathrm{Cl}^{-}\right.$and $\left.\mathrm{NO}_{3}{ }^{-}\right)[28,29]$. The experimental results show good correlation with literature [30]. A strong retardation effect was also observed by $\mathrm{CO}_{3}{ }^{2-}$ and $\mathrm{HCO}_{3}{ }^{-}$. This is due to scavenging effect of $\mathrm{OH}$ radical by $\mathrm{CO}_{3}{ }^{2-}$ and $\mathrm{HCO}_{3}{ }^{-}$[31]. Since the waste water of textile industry contain a number of inorganic salts, among these, $\mathrm{Cl}^{-}$and sulphate ion salt are very common [32]. These ions show negative effect on degradation due to scavenging of ${ }^{\circ} \mathrm{OH}$ radical by $\mathrm{Cl}^{-}$and $\mathrm{SO}_{4}{ }^{2-}$ [33].

\subsection{UV/ PMS $\left(\mathrm{HSO}_{5}{ }^{-}\right) / \mathrm{Fe}^{2+}$ process}

The degradation of $A Y 17$ under various experimental conditions such as $\mathrm{UV}, \mathrm{Fe}^{2+}, \mathrm{HSO}_{5}{ }^{-}, \mathrm{HSO}_{5}{ }^{-} / \mathrm{Fe}^{2+}$ and $\mathrm{UV} /$ $\mathrm{HSO}_{5}{ }^{-} / \mathrm{Fe}^{2+}$ were performed (Fig. 4). In the absence of both oxidant $\left(\mathrm{HSO}_{5}{ }^{-}\right)$and catalyst $\left(\mathrm{Fe}^{2+}\right)$, low percent degradation was observed with UV light. This was due 
to generation of small amount of hydroxyl radical $(\mathrm{OH})$ in water. In UV/Fe ${ }^{2+}$ or UV/ $\mathrm{HSO}_{5}{ }^{-}$systems, the degradation was also low due to lack of catalyst $\left(\mathrm{Fe}^{2+}\right)$ or oxidizing agent $\left(\mathrm{HSO}_{5}{ }^{-}\right)$, vice-versa. In system containing both $\mathrm{HSO}_{5}{ }^{-}$and $\mathrm{Fe}^{2+}$, as the quantity of intermediates are increased, the degradation was reached up to $57 \%$ in 60 min of reaction time, this high degradation was due to the catalytic production of sulphate radical, which attacks the AY 17. The highest degradation (85\%) was achieved by UV assists $\mathrm{HSO}_{5}{ }^{-} / \mathrm{Fe}^{2+}$ system. In this system highly oxidizing species $\mathrm{SO}_{4}^{-}$- radical produced in high amount which attack the dye molecule and degraded it (see Eqns. 18-20) [34].

$\mathrm{Fe}^{2+}+\mathrm{HSO}_{5}^{-} \rightarrow \mathrm{Fe}^{3+}+\mathrm{SO}_{4}^{--}+{ }^{+} \mathrm{H}$

$2 \mathrm{HSO}_{5}^{-}+\mathrm{hv} \rightarrow \mathrm{SO}_{4}^{--}+\mathrm{SO}_{4}^{--}+2 \cdot \mathrm{OH}$

$\mathrm{SO}_{4}^{--}+\mathrm{AY} 17 \rightarrow$ Intermediates

It was observed that $\mathrm{UV} / \mathrm{HSO}_{5}{ }^{-} / \mathrm{Fe}^{2+}$ shows the highest degradation at $\mathrm{pH} 3$. The effect of concentration of $\mathrm{HSO}_{5}{ }^{-}$was also checked by keeping other parameters such as $\mathrm{pH}$, temperature, initial concentration of $\mathrm{Fe}^{2+}(1 \mathrm{mM})$ and AY $17(0.14 \mathrm{mM})$ dye constant. It was observed that degradation of AY 17 dye increased with increased of $\mathrm{HSO}_{5}{ }^{-}$concentration due to production of sulphate radical $\left(\mathrm{SO}_{4}{ }^{-}\right)$. The optimum concentration of $\mathrm{HSO}_{5}{ }^{-}$was found as $2.0 \mathrm{mM}$. The effect of initial concentration of $\mathrm{Fe}^{2+}$ at constant concentration of $\mathrm{AY} 17$ and oxidant $\left(\mathrm{HSO}_{5}{ }^{-}\right)$on the

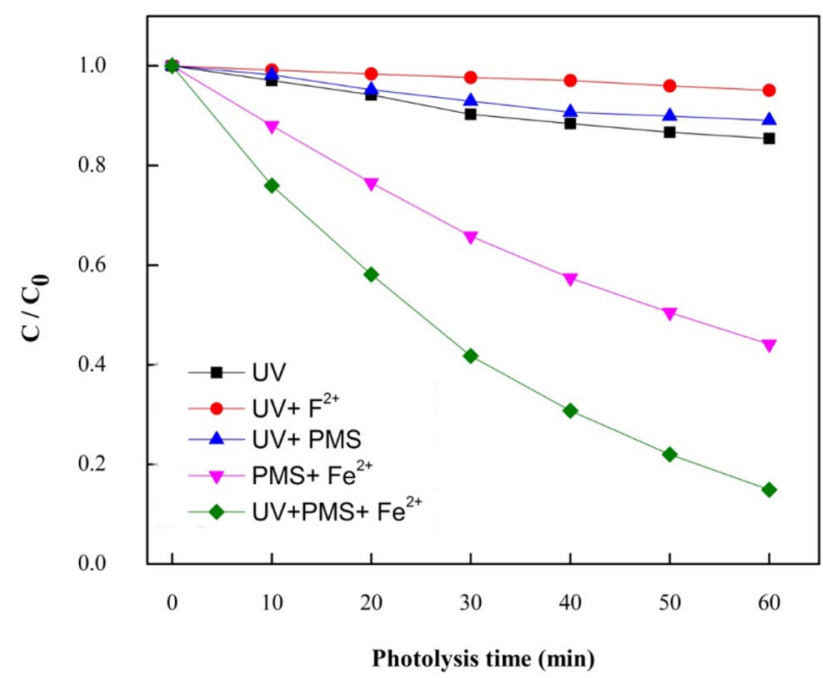

Fig. 4 Effect of various parameters on degradation. Experimental conditions: $\mathrm{pH}=3, \mathrm{~T}=298 \mathrm{~K},\left[\mathrm{HSO}_{5}{ }^{-}\right]_{0}=2 \mathrm{mM},\left[\mathrm{Fe}^{2+}\right]_{0}=1 \mathrm{mM},[\mathrm{AY}$ $17]_{0}=0.14 \mathrm{mM}$

\section{SN Applied Sciences}

A SPRINGER NATURE journal degradation of AY 17 by UV/ $/ \mathrm{HSO}_{5}{ }^{-} / \mathrm{Fe}^{2+}$ was also investigated. The degradation of $A Y 17$ dye increased with $\mathrm{Fe}^{2+}$ concentration. The $\mathrm{Fe}^{2+}$ ion catalyzed the $\mathrm{HSO}_{5}{ }^{-}$to produced reactive sulphate radical $\left(\mathrm{SO}_{4} \cdot-\right)$ through electron transfer mechanism [34].

Decomposition of dye in water by $\mathrm{UV} / \mathrm{HSO}_{5}{ }^{-} / \mathrm{Fe}^{2+}$ also depends on initial concentration of dye AY 17. It was seen that upon increasing the initial concentration of AY 17, percent degradation decreased. The reason for decrease in degradation with increasing AY 17 concentration was the competing reactions of intermediates with $\mathrm{SO}_{4}{ }^{-}$radical which formed during degradation of dye. As the quantity of intermediates are increase during AY 17 degradation, the $\mathrm{SO}_{4}{ }^{-}$radical have greater chance to react with intermediates rather than $\mathrm{AY} 17$ hence the percent degradation of $A Y 17$ decreases [35]. The effect of initial temperature on the degradation of $\mathrm{AY} 17$ by UV/ $\mathrm{HSO}_{5}{ }^{-} / \mathrm{Fe}^{2+}$ process was also studied. At three temperatures (298, 308 and $318 \mathrm{~K})$, the percent degradation was found to be 85,92 , and 94 , respectively. The effect of various inorganic ions such as $\mathrm{HCO}_{3}{ }^{-}$and $\mathrm{CO}_{3}{ }^{2-} \mathrm{SO}_{4}{ }^{2-}$ and $\mathrm{Cl}^{-}$were investigated. It was observed that the presences of these ions have negative effect on the degradation of $\mathrm{AY} 17$ dye by $\mathrm{UV} / \mathrm{HSO}_{5}{ }^{-} / \mathrm{Fe}^{2+}$ process. High concentration of these ions, decrease the degradation of $\mathrm{AY} 17$ dye due to scavenging of $\mathrm{SO}_{4}{ }^{-}$radical [36]. These results obtained in our study was in agreement with literature [37].

\subsection{UV/PS $\left(\mathrm{S}_{2} \mathrm{O}_{8}{ }^{2-}\right) / \mathrm{Fe}^{2+}$ process}

To study the degradation of $\mathrm{AY} 17$ by $\mathrm{UV} / \mathrm{S}_{2} \mathrm{O}_{8}{ }^{2-} / \mathrm{Fe}^{2+}$ system, first AY 17 were decomposed by only UV, UV/ $\mathrm{Fe}^{2+}, \mathrm{UV} / \mathrm{S}_{2} \mathrm{O}_{8}{ }^{2-}, \mathrm{S}_{2} \mathrm{O}_{8}{ }^{2-} / \mathrm{Fe}^{2+}$, and $\mathrm{UV} / \mathrm{S}_{2} \mathrm{O}_{8}{ }^{2-} / \mathrm{Fe}^{2+}$ (Fig. 5). The order of decreasing degradation is given as: UV/ $\mathrm{S}_{2} \mathrm{O}_{8}{ }^{2-} / \mathrm{Fe}^{2+}<\mathrm{S}_{2} \mathrm{O}_{8}{ }^{2-} / \mathrm{Fe}^{2+}<\mathrm{UV} / \mathrm{S}_{2} \mathrm{O}_{8}{ }^{2-}<\mathrm{UV} / \mathrm{Fe}^{2+}<\mathrm{UV}$. The $\mathrm{S}_{2} \mathrm{O}_{8}{ }^{2-} / \mathrm{Fe}^{2+}$ system assist by UV radiation significantly increased the degradation of AY 17 because reactive species such as ${ }^{\circ} \mathrm{OH}$ and $\mathrm{SO}_{4}{ }^{-}$are formed in excess amount. The reactions which favored the increase in the degradation of $A Y 17$ by UV/S ${ }_{2} \mathrm{O}_{8}{ }^{2-} / \mathrm{Fe}^{2+}$ are mentioned in literature by Eqs. (21-33)[38].

$$
\begin{aligned}
& \mathrm{Fe}^{2+}+\mathrm{S}_{2} \mathrm{O}_{8}^{2-} \rightarrow \mathrm{SO}_{4}^{--}+\mathrm{SO}_{4}^{2-}+\mathrm{Fe}^{3+} \\
& \mathrm{Fe}^{3+}+\mathrm{S}_{2} \mathrm{O}_{8}^{2-} \rightarrow 2 \mathrm{SO}_{4}^{--}+\mathrm{Fe}^{2+} \\
& \mathrm{Fe}^{2+}+\mathrm{SO}_{4}^{--} \rightarrow \mathrm{SO}_{4}^{2-}+\mathrm{Fe}^{3+} \\
& \mathrm{H}_{2} \mathrm{O}+\mathrm{SO}_{4}^{--} \rightarrow \mathrm{OH}+\mathrm{HSO}_{4}^{-}
\end{aligned}
$$




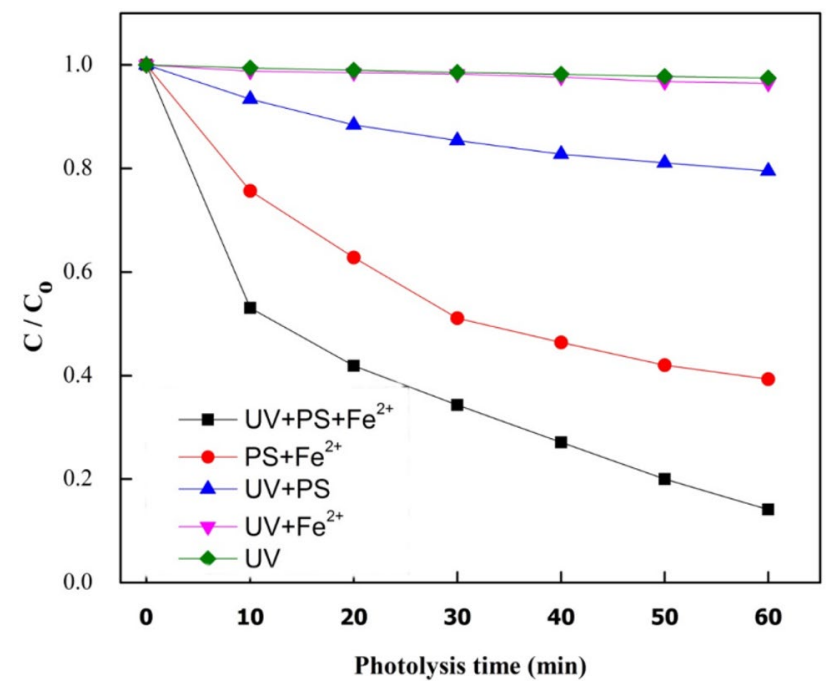

Fig. 5 Effect various parameters on degradation of AY 17 as a function of reaction time. Experimental conditions: $[\mathrm{AY} 17]_{0}=0.14 \mathrm{mM}$, $\left[\mathrm{S}_{2} \mathrm{O}_{8}{ }^{2-}\right]_{0}=1.0 \mathrm{mM},\left[\mathrm{Fe}^{2+}\right]_{0}=0.5 \mathrm{mM}, \mathrm{pH}=3.0$

$$
\begin{aligned}
& \mathrm{SO}_{4}^{--}+\mathrm{S}_{2} \mathrm{O}_{8}^{2-} \rightarrow \mathrm{S}_{2} \mathrm{O}_{8}^{--}+\mathrm{HSO}_{4}^{2-} \\
& \mathrm{S}_{2} \mathrm{O}_{8}^{2-}+\text { Dye } \rightarrow \mathrm{Dye}^{\cdot}+\mathrm{SO}_{4}^{--} \\
& \mathrm{SO}_{4}^{--}+\text {Dye } \rightarrow \text { Dye }+ \text { Products } \\
& \mathrm{S}_{2} \mathrm{O}_{8}^{2-}+\text { Dye } \rightarrow \mathrm{SO}_{4}^{--}+\text {Products } \\
& \mathrm{SO}_{4}^{--}+\mathrm{SO}_{4}^{--} \rightarrow \mathrm{S}_{2} \mathrm{O}_{8}^{2-} \\
& \mathrm{OH}^{-} \mathrm{S}_{2} \mathrm{O}_{2}^{2-} \rightarrow \mathrm{HSO}_{4}^{-}+\mathrm{SO}_{4}^{--}+1 / 2 \mathrm{O}_{2} \\
& \mathrm{OH}^{-\mathrm{SO}_{4}^{--}} \rightarrow \mathrm{HSO}_{4}^{-}+1 / 2 \mathrm{O}_{2} \\
& \mathrm{SO}_{4}^{\cdot-}+\mathrm{H}_{2} \mathrm{O}+\mathrm{hv} \rightarrow^{\cdot} \mathrm{OH}_{+} \mathrm{SO}_{4}^{\cdot-}+{ }^{+} \mathrm{H} \\
& \mathrm{S}_{2} \mathrm{O}_{8}^{2-}+\mathrm{hv}^{-} \rightarrow 2 \mathrm{SO}_{4}^{--}
\end{aligned}
$$

In order to investigate the effect of initial pH on degradation, $\mathrm{A} \mathrm{pH}$ of the dye solution was also change from 3 to 9. It was observed that highest degradation was achieved at $\mathrm{pH} 3$. In acidic $\mathrm{pH}$, the dominant specie was $\mathrm{SO}_{4}{ }^{-}$radical which significantly decomposed the AY 17 dye therefore, the increase of the $\mathrm{pH}$ of solution tend to decrease degradation. At high $\mathrm{pH}$ ( range: 7-9), both $\mathrm{OH}$ and $\mathrm{SO}_{4}{ }^{-}$radical exist which recombine with each other much fast, hence the degradation decreased [39]. The initial concentration of $\mathrm{S}_{2} \mathrm{O}_{8}{ }^{2-}$ also affect decomposition of dye. The optimum concentration of $\mathrm{S}_{2} \mathrm{O}_{8}{ }^{2-}$ was found to be $1 \mathrm{mM}$. The effect of initial concentration of $\mathrm{Fe}^{2+}$ on degradation of $\mathrm{AY} 17$ by $\mathrm{UV} / \mathrm{S}_{2} \mathrm{O}_{8}{ }^{2-} / \mathrm{Fe}^{2+}$ process was also examined. The results show that when then the concentration of $\mathrm{Fe}^{2+}$ increased from 0.05 to $0.5 \mathrm{mM}$ the percent degradation increased considerably. At optimum condition the ratio between of $\mathrm{Fe}^{2+}$ and $\mathrm{S}_{2} \mathrm{O}_{8}{ }^{2-}$ were found to be $1: 2$. The effect of AY 17 dye concentration has also been investigated. the results degradation decreased with dye concentration. The effect of temperature on dye degradation was also monitored. During temperature study, other parameters such as initial $\mathrm{pH}$, concentration of $\mathrm{AY} 17, \mathrm{Fe}^{2+}$ and $\mathrm{S}_{2} \mathrm{O}_{8}{ }^{2-}$ were kept constant. From the results, it is proposed that high temperature has positive effect on the degradation of AY 17 due to the fact that per sulfate can also be thermally activated to produce sulfate radical [40]. It was also ascertained that the concentration of carbonate $\left(\mathrm{CO}_{3}{ }^{2-}\right)$ and bicarbonate $\left(\mathrm{HCO}_{3}{ }^{-}\right)$ions decreased degradation process. In absence of carbonate ion the percent degradation was $86 \%$, while in the presence of $0.01,0.1$ and $0.5 \mathrm{mM}$ carbonate concentration the \% degradation decreased to 81,74 and $69 \%$ respectively. Similarly, in the absence of bicarbonate ion degradation was $86 \%$, but in presence of $0.01,0.1$ and $0.5 \mathrm{mM}$ the percent degradation were slightly decreased to 81,79 and $76 \%$ respectively. The decreased in percent degradation was due to the scavenging effect of sulphate and hydroxyl radical [41]. The effect of chloride and sulphate ion show slight negative effect on degradation.

\subsection{Identification of degradation products and proposed degradation pathway}

GC-MS analysis of AY 17 solutions which was treated with $\mathrm{UV} / \mathrm{H}_{2} \mathrm{O}_{2} / \mathrm{Fe}^{2+}$ process has already been reported in our previous study [31]. It was also reported that during degradation, nine degradation intermediates product were formed through photo-Fenton process while after $25 \mathrm{~min}$ of reaction times the intermediates product was completely decomposed into inorganic ions.

Degradation mechanism of $\mathrm{AY} 17$ by $\mathrm{UV} / \mathrm{S}_{2} \mathrm{O}_{8}{ }^{2-} / \mathrm{Fe}^{2+}$ process at $\mathrm{pH} 3$ is showed in Fig. 6. During the degradation reaction, the spectrum was also recorded for monitoring intermediates products (Fig. 7). It was found that after $60 \mathrm{~min}$, all the degradation products were converted into simple inorganic ions (Fig. 8). The structures of degradation intermediates were obtained from their degree of protonation, chemical formula and $\mathrm{m} / \mathrm{z}$ value. From GC spectrum it was ascertained that the major degradation product, $\mathrm{C}_{6} \mathrm{H}_{4} \mathrm{O}_{2}$ (DP2) with 100 percent relative abundance was obtained at retention time of 2.75 and $3.06 \mathrm{~min}$ (Fig. 8). The degradation product 


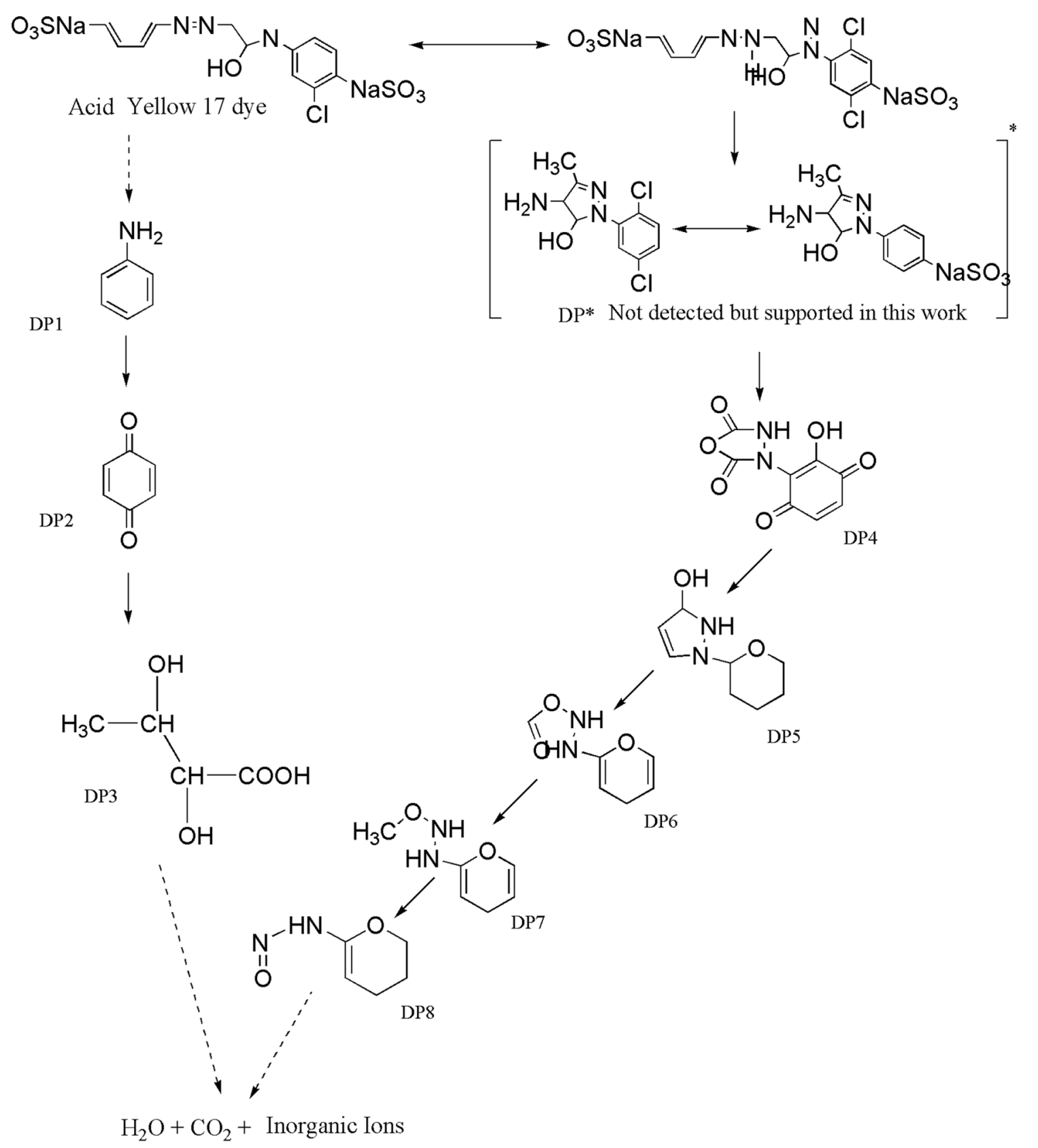

Dotted arrows represents multiple steps involved

Fig. 6 Proposed degradation pathway of $\mathrm{AY} 17$ by UV/S $\mathrm{S}_{2} \mathrm{O}_{8}{ }^{2-} / \mathrm{Fe}^{2+}$ process

(DP1) was monitored at retention time 1.65 with relative abundance $20 \%$. Other degradation products (DP3, DP4, DP5, DP6, DP7 and DP8) were monitored at retention time (4.46/4.89) 4.56, 6.03, $7.468 .82,10.10 / 12.49$ and $14.65 \mathrm{~min}$ have relative abundance round about in between 15 to $20 \%$. The degradation products (DP8) have relative abundance less than $10 \%$. The proposed degradation mechanism of AY 17 dye by (UV/ $\left.\mathrm{S}_{2} \mathrm{O}_{8}{ }^{2-} / \mathrm{Fe}^{2+}\right)$ process is given in Fig. 6 .

\subsection{Degradation of dye by UV light-assist AOPs in model and natural water sample: comparison}

The efficiency of AOPs for degradation were checked in tape and model (prepared in triply distilled) water sample. It was observed that the degradation is maximum in model water sample as compared to natural water sample (Table.3). The reason for such a low degradation was the presence of certain anions are present in aqueous medium such as $\mathrm{CO}_{3}{ }^{2-}(0.252 \mathrm{mM}), \mathrm{HCO}_{3}{ }^{-}(0.298 \mathrm{mM})$, 
Fig. 7 GC spectra of AY 17 dye during $\mathrm{UV} / \mathrm{S}_{2} \mathrm{O}_{8}{ }^{2-} / \mathrm{Fe}^{2+}$ process for identification of intermediates

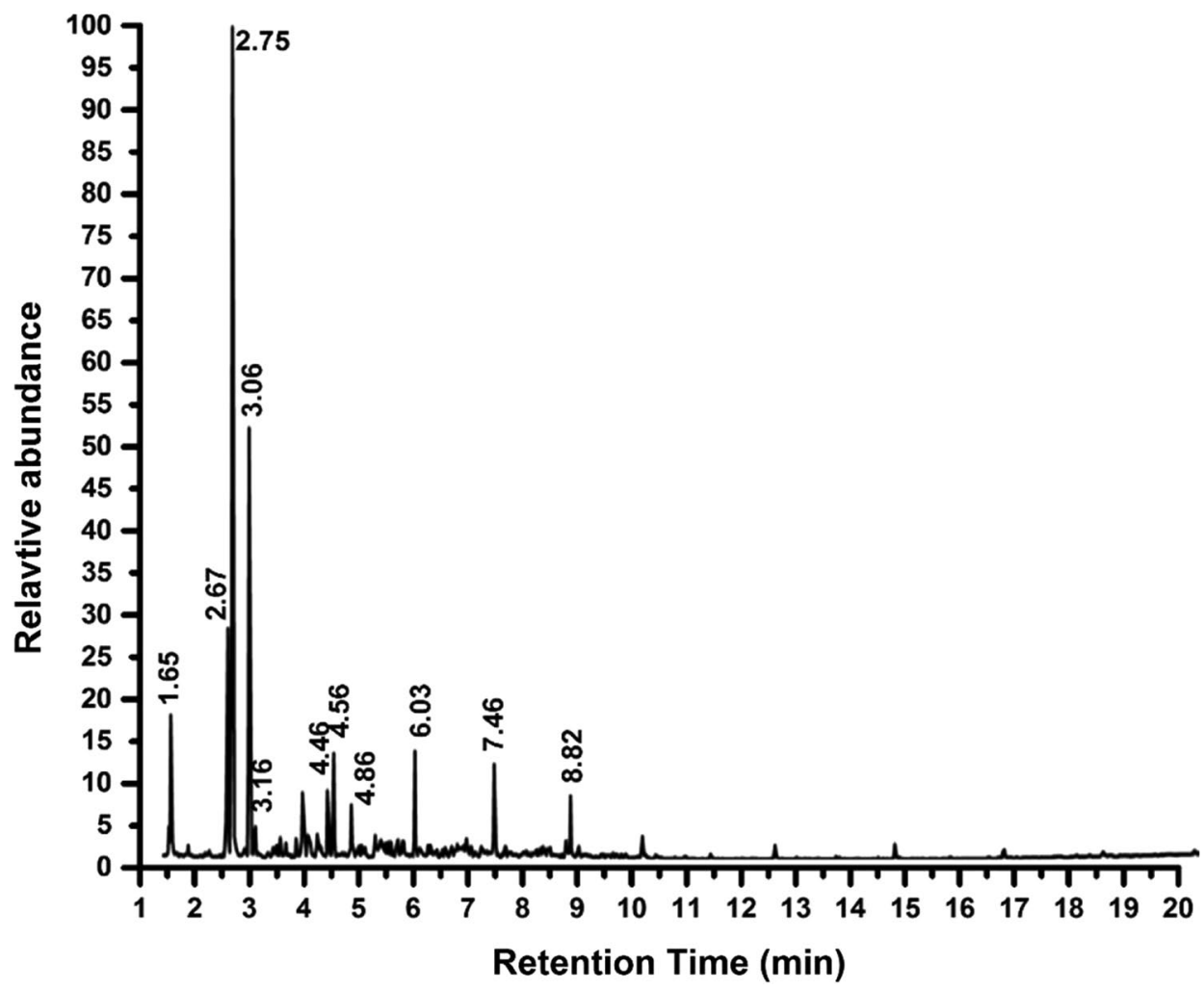

$\mathrm{Cl}^{-}(0.335 \mathrm{mM})$, and $\mathrm{SO}_{4}{ }^{2-}(0.5 \mathrm{mM})$ as confirmed by lon Chromatography (IC). These anions act as scavengers for hydroxyl radical [42]. The trend of degradation of natural water sample of AY 17 shows that the photo-Fenton like process is excellent method for the degradation of both model and natural water sample.

\subsection{Effect of temperature}

The rate of chemical reaction, product yield, and distribution critically depend upon the temperature of system. In the present work the effect of temperature on rate of reaction were determined by changing temperature from 298 to $318 \mathrm{~K}$. It was observed that the degradation increased with temperature due to the fact that at higher temperature, oxidizing species (like $\mathrm{OH}$ radical $\mathrm{SO}_{4}{ }^{-}$radical) are generated in high quantity from oxidants (i.e. $\mathrm{H}_{2} \mathrm{O}_{2}$ $/ \mathrm{HSO}_{5}$ or $\mathrm{S}_{2} \mathrm{O}_{8}$ ) [20,43]. The activation energy, entropy and enthalpy of the degradation can be determined using straight line Eq. (35)

$\operatorname{lnk}=\ln A-E_{a}^{*} / R T$

Ink $=\Delta S^{*}-\Delta H^{*} / R T$

where, $k_{1}$ is the rate constant (pseudo-first- order reaction rate constant), $T$ is temperature of solution in Kelvin $(K), A$ is the Arrhenius constant, R is ideal gas constant
$(0.0082 \mathrm{~kJ} / \mathrm{mol} . \mathrm{K})$ and $\mathrm{E}_{\mathrm{a}}$ is the activation energy. The thermodynamic parameter values are given in Table 4. Low activation energy value $(9.545-17.60 \mathrm{~kJ} / \mathrm{mol})$ may show that the photo-assist AOPs were proceeds with low energy barrier.

\section{Conclusions}

From present work, it was concluded that among several photo assist AOPs, photo-Fenton like process is an efficient process for degradation of AY17 dye in natural water samples. The optimum $\mathrm{pH}$ for all processes was determined as about $\sim 3$. The optimum concentration ratio of oxidants $\left(\mathrm{H}_{2} \mathrm{O}_{2}, \mathrm{HSO}_{5}{ }^{-}\right.$or $\left.\mathrm{S}_{2} \mathrm{O}_{8}{ }^{2-}\right)$ and catalyst $\left(\mathrm{Fe}^{2+}, \mathrm{Fe}^{3+}\right)$ for photo-Fenton, photo-Fenton-like, UV/ $\mathrm{HSO}_{5}{ }^{-} / \mathrm{Fe}^{2+}$ and $\mathrm{UV} / \mathrm{S}_{2} \mathrm{O}_{8}{ }^{2-} / \mathrm{Fe}^{2+}$ process were evaluated to be 11: 1, 111: 1, 15: 1, 14: 7, and 7: 3.5 respectively. A 100-rpm stirring speed was found to optimum. It was seen that degradation increased with increased in temperature. It was also observed that various anions such as $\mathrm{CO}_{3}{ }^{2-}, \mathrm{HCO}_{3}{ }^{-}, \mathrm{Cl}^{-}$and $\mathrm{SO}_{4}{ }^{2-}$ decreased the degradation efficiency. The overall decreased in degradation by anions were in order were found to be $\mathrm{CO}_{3}{ }^{2-}<\mathrm{HCO}_{3}{ }^{-}<\mathrm{Cl}^{-}<\mathrm{SO}_{4}{ }^{2-}$. The degradation of AY 17 dye by photo-assist AOPs in this study followed pseudo-first-order kinetics. The efficiency of AOPs was 
Fig. 8 GC Spectra of AY 17 dye after $60 \mathrm{~min}$ of $\mathrm{UV} / \mathrm{S}_{2} \mathrm{O}_{8}{ }^{2-} / \mathrm{Fe}^{2+}$ process

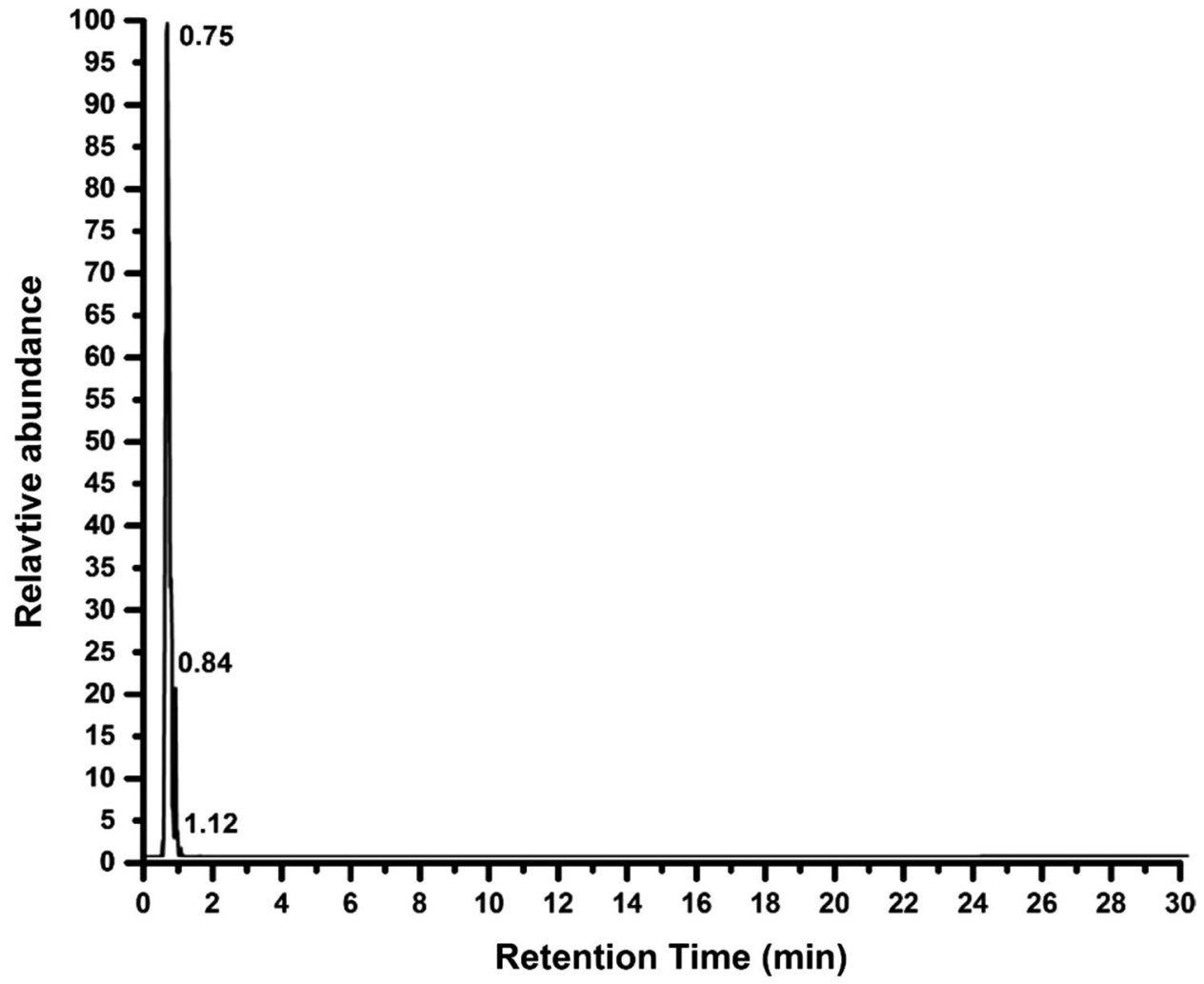

observed to be high in model (triply distilled water) sample than natural water sample. The photo Fenton process decompose AY 17 dye in less time as compared to

Table 3 Efficiency of various UV light assist AOPs for model and natural water sample

\begin{tabular}{lllll}
\hline Sample & $\mathrm{UV} / \mathrm{H}_{2} \mathrm{O}_{2} / \mathrm{Fe}^{2+}$ & $\mathrm{UV} / \mathrm{H}_{2} \mathrm{O}_{2} / \mathrm{Fe}^{3+}$ & $\begin{array}{l}\mathrm{UV} / \\
\mathrm{HSO}_{5}{ }^{-} / \\
\mathrm{Fe}^{2+}\end{array}$ & $\begin{array}{l}\mathrm{UV} / \\
\mathrm{S}_{2} \mathrm{O}_{8}{ }^{2-} / \\
\mathrm{Fe}^{2+}\end{array}$ \\
& \multicolumn{2}{l}{ Percent degradation } & \\
\hline Model & 88 & 93 & 86 & 84 \\
Natural & 43 & 60 & 65 & 63 \\
\hline
\end{tabular}

other processes. The activation energies $(\mathrm{KJ} / \mathrm{mol})$ were also different, the increasing order of activation energy is $(\text { Fenton-like }=9.487)^{<}$(photo Fenton $\left.=9.545\right)^{<}$(photoFenton-like $=12.88)^{<}\left(\mathrm{UV} / \mathrm{HSO}_{5}-/ \mathrm{Fe}^{2+}=16.74\right)^{<}(\mathrm{UVH} /$ $\left.\mathrm{S}_{2} \mathrm{O}_{8}{ }^{2-} / \mathrm{Fe}^{2+}=17.60\right)$. The entropy (KJ/mol.K) of applied process were in order (photo Fenton $=0.0124)^{<}$(photoFenton-like $=0.0183)^{<}\left(\mathrm{UV} / \mathrm{HSO}_{5}{ }^{-} / \mathrm{Fe}^{2+}=0.0283\right)^{<}(\mathrm{UVH} /$ $\left.\mathrm{S}_{2} \mathrm{O}_{8}{ }^{2-} / \mathrm{Fe}^{2+}=0.0314\right)$. The order of $\%$ degradation of natural water was in order (photo Fenton) ' (photo-Fenton-like $)^{<}\left(\mathrm{UV} / \mathrm{S}_{2} \mathrm{O}_{8}{ }^{2-} / \mathrm{Fe}^{2+}\right)^{<}\left(\mathrm{UV} / \mathrm{HSO}_{5}{ }^{-} / \mathrm{Fe}^{2+}\right)$.
Table 4 Kinetic parameters for degradation of AY 17 for various AOPs

\begin{tabular}{lllll}
\hline Kinetic parameter & $\mathrm{UV} / \mathrm{H}_{2} \mathrm{O}_{2} / \mathrm{Fe}^{2+}$ & $\mathrm{UV} / \mathrm{H}_{2} \mathrm{O}_{2} / \mathrm{Fe}^{3+}$ & $\mathrm{UV} / \mathrm{HSO}_{5}{ }^{-} / \mathrm{Fe}^{2+}$ & $\mathrm{UV} / \mathrm{S}_{2} \mathrm{O}_{8}{ }^{2-} / \mathrm{Fe}^{2+}$ \\
\hline$E_{a}{ }^{*} \mathrm{~kJ} / \mathrm{mol}$ & 9.545 & 12.88 & 16.74 & 17.60 \\
$\Delta \mathrm{S}^{*} \mathrm{~kJ} / \mathrm{mol} . \mathrm{K}$ & 0.0124 & 0.0183 & 0.0284 & 0.0314 \\
\hline
\end{tabular}




\section{Compliance with ethical standards}

Conflict of interest The authors declare that they have no conflicts of interest.

\section{References}

1. Khan JA, He X, Khan HM et al (2013) Oxidative degradation of atrazine in aqueous solution by $\mathrm{UV} / \mathrm{H}_{2} \mathrm{O}_{2} / \mathrm{Fe}^{2+}, \mathrm{UV} / \mathrm{S}_{2} \mathrm{O}_{8}{ }^{2-} / \mathrm{Fe}^{2+}$ and UV/ $/ \mathrm{HSO}^{5-} / \mathrm{Fe}^{2+}$ processes: a comparative study. Chem Eng J 218:376-383

2. Dionysiou DD, Suidan MT, Baudin I, Laîné J-M, (2004) Effect of hydrogen peroxide on the destruction of organic contaminants-synergism and inhibition in a continuous-mode photocatalytic reactor. Appl Catal B Environ 50:259-269

3. Wordofa DN, Walker SL, Liu H (2017) Sulfate radical-induced disinfection of pathogenic Escherichia coli 0157: H7 via ironactivated persulfate. Environ Sci Technol Lett 4:154-160

4. Liu CS, Shih K, Sun CX, Wang F (2012) Oxidative degradation of propachlor by ferrous and copper ion activated persulfate. Sci Total Environ 416:507-512

5. Tamimi M, Qourzal S, Barka N et al (2008) Methomyl degradation in aqueous solutions by Fenton's reagent and the photoFenton system. Sep Purif Technol 61:103-108

6. He X (2014) Kinetic and mechanistic studies on the removal of cyanotoxins and antibiotics with hydroxyl and sulfate radical based advanced oxidation processes. University of Cincinnati, Cincinnati

7. Rodrigo MA, Poulios I, Mantzavinos D, Dewil R (2017) New perspectives for advanced oxidation processes

8. Parsons S (2004) Advanced oxidation processes for water and wastewater treatment. IWA publishing, London

9. Liu X, Qiu M, Huang C (2011) Degradation of the reactive black 5 by Fenton and Fenton-like system. Procedia Eng 15:4835-4840

10. Iqbal M, Bhatti IA (2015) Gamma radiation $/ \mathrm{H}_{2} \mathrm{O}_{2}$ treatment of a nonylphenol ethoxylates: degradation, cytotoxicity, and mutagenicity evaluation. J Hazard Mater 299:351-360

11. Anipsitakis GP, Dionysiou DD (2004) Transition metal/UVbased advanced oxidation technologies for water decontamination. Appl Catal B Environ 54:155-163

12. Razo-Flores E, Luijten M, Donlon BA et al (1997) Complete biodegradation of the azo dye azodisalicylate under anaerobic conditions. Environ Sci Technol 31:2098-2103

13. Pinheiro HM, Touraud E, Thomas O (2004) Aromatic amines from azo dye reduction: status review with emphasis on direct UV spectrophotometric detection in textile industry wastewaters. Dye Pigment 61:121-139. https://doi.org/10.1016/j.dyepi g.2003.10.009

14. Jadhav I, Vasniwal R, Shrivastava D, Jadhav K (2016) Microorganism-based treatment of azo dyes. J Environ Sci Technol 9:188-197. https://doi.org/10.3923/jest.2016.188.197

15. Gupta VK, Suhas, (2009) Application of low-cost adsorbents for dye removal-a review. J Environ Manag 90:2313-2342

16. Nogueira RFP, Trovó AG, da Silva MRA et al (2007) Fundaments and environmental applications of Fenton and photo-Fenton processes. Quim Nova 30:400-408

17. Arslan-Alaton I, Gursoy BH, Schmidt J-E (2008) Advanced oxidation of acid and reactive dyes: effect of Fenton treatment on aerobic, anoxic and anaerobic processes. Dye Pigment 78:117-130

18. Ammar HB, Ben BM, Abdelhédi R, Samet $Y$ (2016) Enhanced degradation of metronidazole by sunlight via photo-Fenton process under gradual addition of hydrogen peroxide. $\mathrm{J} \mathrm{Mol}$ Catal A Chem 420:222-227

19. Daneshvar N, Behnajady MA, Mohammadi MKA, Dorraji MSS (2008) $\mathrm{UV} / \mathrm{H}_{2} \mathrm{O}_{2}$ treatment of Rhodamine $\mathrm{B}$ in aqueous solution: influence of operational parameters and kinetic modeling. Desalination 230:16-26

20. Sun J, Sun S, Wang G, Qiao L (2007) Degradation of azo dye Amido black $10 \mathrm{~B}$ in aqueous solution by Fenton oxidation process. Dye Pigment 74:647-652. https://doi.org/10.1016/j. dyepig.2006.04.006

21. Ghiselli G, Jardim WF, Litter MI, Mansilla HD (2004) Destruction of EDTA using Fenton and photo-Fenton-like reactions under UV-A irradiation. J Photochem Photobiol A Chem 167:59-67

22. Qi Y, Shang C, Lo IMC (2004) Formation of haloacetic acids during monochloramination. Water Res 38:2375-2383

23. De Laat J, Le GT, Legube B (2004) A comparative study of the effects of chloride, sulfate and nitrate ions on the rates of decomposition of $\mathrm{H} 2 \mathrm{O} 2$ and organic compounds by $\mathrm{Fe}(\mathrm{II}) / \mathrm{H}_{2} \mathrm{O}_{2}$ and $\mathrm{Fe}(\mathrm{III}) / \mathrm{H}_{2} \mathrm{O}_{2}$. Chemosphere 55:715-723

24. Lee $\mathrm{C}$, Yoon $\mathrm{J}$ (2004) Temperature dependence of hydroxyl radical formation in the hv/ $\mathrm{Fe}^{3+} / \mathrm{H}_{2} \mathrm{O}_{2}$ and $\mathrm{Fe}^{3+} / \mathrm{H}_{2} \mathrm{O}_{2}$ systems. Chemosphere 56:923-934

25. Bautista P, Mohedano AF, Casas JA et al (2008) An overview of the application of Fenton oxidation to industrial wastewaters treatment. J Chem Technol Biotechnol Int Res Process Environ Clean Technol 83:1323-1338

26. Jia Z, Zhang WC, Wang WM et al (2016) Amorphous $\mathrm{Fe}_{78} \mathrm{Si}_{9} \mathrm{~B}_{13}$ alloy: An efficient and reusable photo-enhanced Fenton-like catalyst in degradation of cibacron brilliant red 3B-A dye under UV-vis light. Appl Catal B Environ 192:46-56

27. Tang WZ, Chen RZ (1996) Decolorization kinetics and mechanisms of commercial dyes by $\mathrm{H}_{2} \mathrm{O}_{2}$ /iron powder system. Chemosphere 32:947-958

28. Arslan-Alaton I, Tureli G, Olmez-Hanci T (2009) Treatment of azo dye production wastewaters using Photo-Fenton-like advanced oxidation processes: optimization by response surface methodology. J Photochem Photobiol A Chem 202:142-153

29. Elmorsi TM, Riyad YM, Mohamed ZH, El Bary HMHA (2010) Decolorization of Mordant red 73 azo dye in water using $\mathrm{H}_{2} \mathrm{O}_{2} / \mathrm{UV}$ and photo-Fenton treatment. J Hazard Mater 174:352-358

30. Vergara-Sánchez J, Pérez-Orozco JP, Suárez-Parra R, HernándezPérez I (2012) Degradation of reactive red 120 azo dye in aqueous solutions using homogenous/heterogenous Iron systems. Rev Mex Ing Química 11:121-131

31. Khan J, Tariq M, Muhammad M et al (2020) Application of PhotoFenton System (UV/ $\mathrm{H}_{2} \mathrm{O}_{2} / \mathrm{Fe}^{2+}$ ) for Efficient Decolorization of Azo-Dye Acid Yellow 17 in Aqueous Solution. Iran J Chem Eng 39:127-140

32. Chen G, Chai X, Po-Lock Y, Mi Y (1997) Treatment of textile desizing wastewater by pilot scale nanofiltration membrane separation. J Memb Sci 127:93-99

33. Dong Y, Chen J, Li C, Zhu H (2007) Decoloration of three azo dyes in water by photocatalysis of $\mathrm{Fe}(\mathrm{III})$-oxalate complexes $/ \mathrm{H}_{2} \mathrm{O}_{2}$ in the presence of inorganic salts. Dye Pigment 73:261-268

34. Antoniou MG, Armah A, Dionysiou DD (2010) Degradation of microcystin-LR using sulfate radicals generated through photolysis, thermolysis and e-transfer mechanisms. Appl Catal B Environ 96:290-298

35. Ghauch A, Tuqan AM, Kibbi N (2012) Ibuprofen removal by heated persulfate in aqueous solution: a kinetics study. Chem Eng J 197:483-492

36. Burbano AA, Dionysiou DD, Suidan MT, Richardson TL (2005) Oxidation kinetics and effect of $\mathrm{pH}$ on the degradation of MTBE with Fenton reagent. Water Res 39:107-118. https://doi. org/10.1016/j.watres.2004.09.008 
37. Rehman F, Sayed M, Khan JA et al (2018) Oxidative removal of brilliant green by UV/S2O82-, UV/HSO5-and UV/H2O2 processes in aqueous media: a comparative study. J Hazard Mater 357:506-514

38. Sizykh M, Batoeva A, Tsydenova O (2018) UV-activated persulfate oxidation of orange III dye using $\mathrm{KrCl}$ Excilamp. CLEAN-Soil Air Water 46:1700187

39. Deng J, Shao Y, Gao N et al (2013) Degradation of the antiepileptic drug carbamazepine upon different UV-based advanced oxidation processes in water. Chem Eng J 222:150-158. https:// doi.org/10.1016/j.cej.2013.02.045

40. Waldemer RH, Tratnyek PG, Johnson RL, Nurmi JT (2007) Oxidation of chlorinated ethenes by heat-activated persulfate: kinetics and products. Environ Sci Technol 41:1010-1015
41. Yang Y, Pignatello JJ, Ma J, Mitch WA (2014) Comparison of halide impacts on the efficiency of contaminant degradation by sulfate and hydroxyl radical-based advanced oxidation processes (AOPs). Environ Sci Technol 48:2344-2351

42. Dutta K, Mukhopadhyay S, Bhattacharjee S, Chaudhuri B (2001) Chemical oxidation of methylene blue using a Fenton-like reaction. J Hazard Mater 84:57-71

43. Idel-aouad R, Valiente M, Yaacoubi A et al (2011) Rapid decolourization and mineralization of the azo dye $\mathrm{Cl}$ Acid Red 14 by heterogeneous Fenton reaction. J Hazard Mater 186:745-750

Publisher's Note Springer Nature remains neutral with regard to jurisdictional claims in published maps and institutional affiliations. 